\title{
VEHNÄN KVALITEETTIJALOSTUKSESTA JA SEN TULOKSISTA SUOMESSA
}

\author{
Vilho A. Pesola ja Teemu Veijola \\ Maatalouskoelaitoksen kasvinjalostusosasto, Jokioinen, ja Valtion teknillisen tutki- \\ muslaitoksen elintarviketeollisuuslaboratorio, Helsinki
}

Saapunut 18,9.1954.

Maamme valtiollisen itsenäisyyden alkuvuosina, 1920-luvun alussa ja sitä ennen, maamme vehnäntuotanto oli vain $10-15$ milj. $\mathrm{kg}$, mikä tyydytti ainoastaan pienen osan vehnän tarpeestamme. Kotimaisen vehnän laatuun, sen leivontakelpoisuuteen ei näihin aikoihin kiinnitetty mainittavaa huomiota. Suunniteltaessa eräitä kotimaisen viljantuotannon edistämistä tarkoittavia toimenpiteitä kävi kotimaisen vehnän, kuten muunkin viljan laadun tuntemus tarpeelliseksi. Ensimmäiset tällaiset tutkimukset kohdistuivat vuosien 1924 ja 1926 satoon $(20,23)$.

Monet tekijät aiheuttivat, että vehnän, erityisesti kevätvehnän viljely alkoi 1930-luvun alusta alkaen voimakkaasti laajeta. Jo 5-vuotiskautena 1936-1940 maassamme tuotettiin vehnää keskim. noin 200 milj. kg, mikä tyydytti noin 70 $80 \%$ silloisesta kulutuksesta. Tästä vehnäsadosta oli noin $4 / 5$ kevätvehnää. Sotain jälkeen on vehnän viljely edelleen laajentunut. Vuonna 1952 oli vehnän kokonaissato noin 230 milj. kg, mistä noin 90 \% oli kevätvehnää. Mutta kulutuksen lisäännyttyä oli omavaraisuus viime vuonna vehnässä vain noin $50 \%$. On toivottavaa ja myös todennäköistä, että vehnäntuotanto maassamme tulee lähivuosina lisääntymään, luultavasti pääasiallisesti syysvehnän varassa. Päämääränä, joka lienee myös saavutettavissa, tulisi olla noin $90 \%$ omavaraisuus.

On luonnollista, että vehnänviljelyn alkaessa 1930-luvulla ripeästi laajentua kotimaassa tuotetun vehnän leivontakelpoisuutta ryhdyttiin aikaisempaa tehokkaammin tutkimaan. Näistä siis jo noin kolmen vuosikymmenen ajan jatkuneista tutkimuksista ja niiden tuloksista ovat Tomula $(20-23)$, Pesola $(8,9$.), Pesola ja OTtERStröm (12), VEiJOLA (24-31) tehneet selkoa, ja ne tarjoavat jo varsin käyttökelpoisen perustan meillä tuotetun vehnän kvaliteetin ymmärtämiseksi (vrt. myös 13 ym. tutkimukset kirjallisuusluettelossa).

Vehnän laatu 1. kvaliteetti, sen leivontakelpoisuus riippuu lähinnä vehnän jyvän sisältämäin valkuais- 1. proteiiniaineiden, lähinnä sitkoaineen 1. gluteenin määrästä ja laadusta. Sekä edellä mainitut kotimaiset tutkimukset että monet ulkomailla 
suoritetut ovat osoittaneet, että vehnän laatuun vaikuttavat sekä ulkoiset, siis viljelyolosuhteet että perinnölliset 1. geneettiset tekijät (vrt. mm. 4, 19). Laadultaan erinomaista vehnää tuotetaan esim. Kanadan mantereellisilmastollisilla "mustan mullan» alueilla. Typpilannoituksella voidaan jyväin proteiinipitoisuutta kohottaa, kuten mm. eräät meillä ja Ruotsissa suoritetut tutkimukset osoittavat (1, 28 ym.).

Meidän viljelyolosuhteitamme ajateltaessa on erityisen tärkeätä, että vehnä (tämä koskee erityisesti kevätvehnää) on riittävän aikaista, joten se ehtii normaalisesti tuleentua. Loppukesän ja alkusyksyn sateiset säät saattavat vaarantaa vehnän laadun ulkokuivauksen aikana, mainitaksemme vain eräitä tärkeimpiä niistä ulkoisista 1. ympäristötekijöistä, jotka vaikuttavat vehnän laatuun (vrt. myös 5).

Kuten jo edellä mainittiin vaikuttavat vehnän kvaliteettiin myös perintötekijät, ts. vehnän laatu ilmenee osaltaan myös ns. lajikeominaisuuden tavoin, mikä seikka on tuonut ja tuo tämän kysymyksen myös kasvinjalostajan työpiiriin. Varsinkin 192C - 1930-luvun vaihteesta alkaen kasvinjalostajat meillä, niin hyvin Hankkijan kasvinjalostuslaitoksessa Tammistossa kuin Maatalouskoelaitoksen kasvinjalostusosastolla Jokioisissa ovat työssään kiinnittäneet suurta huomiota vehnän leivontakelpoisuuteen.

Minkälaista oli Suomessa 1930-luvun alussa viljelty vehnä leivontaominaisuuksiltaan? Pesola (9) on, nojautuen siihen asti suoritettuihin tutkimuksiin, esittänyt siitä yleispiirteisen katsauksen (vrt. myös 8 ym.). Esityksessä vehnät jaetaan niiden laadun perusteella Pelshenken $(6,7)$ mukaan 3 ryhmään, nim. A, B ja C vehniin. A luokan vehniin ns. vahvoihin vehniin kuuluvat sellaiset vehnät (vehnämerkit tai -lajikkeet), joita sitkoaineensa oivallisuuden perusteella voidaan sekottaa toisiin, huonoihin vehniin, niiden parantamiseksi. Esimerkkinä tällaisesta A luokan vehnästä voidaan mainita tunnettu kanadalainen Manitoba-vehnä (varsinkin sen parhaat luokat). B luokan vehnät ovat keskinkertaisia, sellaisenaankin käytäntöön soveliaita. C luokan vehniin, ns. heikkoihin vehniin täytyy sekottaa parempia, vahvempia vehniä. Jos niitä jauhetaan ja leivotaan yksikseen, ei niistä saatu leipä ole tyydyttävää.

Mainitun tutkielman mukaan meillä 1920-luvun lopussa ja 1930-luvun alussa viljellyt syysvehnät, niin hyvin kotimaiset (maatiaisvehnät keskimäärin, Sukkulavehnät, Sampo, Panu, Pohjola ym.) kuin ruotsalaiset (Thule II, Svea I, Jarl ym.) kuuluvat C luokkaan (tai C+ luokkaan). Silloin oli syysvehnästä näköpiirissä jo parempiakin linjoja. Kevätvehnistä merkittiin maatiaisvehnät ryhmiin $\mathrm{C}-\mathrm{B}$, kotimaiset jalosteet (Pika, Pika II ja Ruskea) ryhmään C $(\mathrm{C}+$ ) ja Suomessa silloin jonkinverran viljelty ulkomainen jaloste (Aurore) samoin ryhmään C.

Seuraavassa tarkastetaan, minkälaisiin tuloksiin on Suomessa 1930- ja 1940luvuilla päästy vehnän kvaliteettijalostuksen alalla. Samalla tarkastetaan meillä tuona aikana viljeltyjä tärkeimpiä ulkomaisia (pääasiallisesti ruotsalaisia, Svalöfin ja Weibullsholmin) jalosteita. Tarkastelu nojautuu pääasiallisesti oheisiin taulukkoihin.

Taulukoissa 1-10 esitetään seuraavat vehnän jyvän ja jauhon (leivän) 1 a atua kuvaavat ominaisu ude t: hl-paino, raakaproteiini (kuivaaineesta), Pelshenke- 1. kesto-(rouhe-)luku, farinogrammista laskettu ns. valorimetri- 
1. hyvyysluku, jauhon vedensitomiskyky, leivän paino (100 g:sta jauhoa) ja leivän tilavuus, ilman parannusaineita (I) ja kaliumbromaatilla $(0.003 \%)$ käsiteltynä (II) sekä huokoisuus (MoHsin asteikko). Hl-paino-, rouhe- ja farinografimääritykset on suoritettu osaksi Maatalouskoelaitoksen kasvinjalostusosastolla Jokioisissa, osaksi Valtion teknillisen tutkimuslaitoksen elintarviketeollisuuslaboratoriossa (Viljantutkimuslaitoksessa), kaikki muut määritykset on, pienin poikkeuksin, suoritettu viimemainitussa paikassa.

Tutkimuksiin käytetty a in e is t o on saatu Maatalouskoelaitoksen kasvinviljelysosastolta Tikkurilasta ja saman laitoksen kasvinjalostusosastolta Jokioisista, Tammiston kasvinjalostuslaitokselta Malmilta ja eräiltä kasvinviljelyskoeasemilta.

Ainekset taulukkoihin on kerätty osaksi julkaisuista (varsinkin VEIJOLAn, ks. kirjallis.luett.), osaksi Jokioisten kasvinjalostuslaitoksen ja Viljantutkimuslaitoksen alkuperäisistä pöytäkirjoista.

Käytetyistä tutkimusmenetelmistä mainittakoon vain, että Pelshenke-menetelmä on lähinnä kasvinjalostukseen tarkoitettu karkeapiirteinen pikamenetelmä ja että farinografilla saadaan ilmi lähinnä jauhon vedensitomiskyky sekä taikinan kimmoisuus ja kestävyys, mitkä viimemainitut seikat voidaan tietyin tavoin farinogrammista lukien merkitä ns. valorimetri- 1. hyvyyslukuna. Hyvänä leipätuloksena mainitsee Åkerman ym. (35) vähintään 159 g (100 g:sta jauhoa) leivän painon, Kosmin (3) pitää normaalisena 160 - 165 g painoista leipää. Normaalisena leipätilavuutena pitää Kosmin ilman parannusaineita leivottaessa $500 \mathrm{ml}$ tilavuutta, Åkerman ym. (35) vähintään $650 \mathrm{ml}$ tilavuutta, kemikalioita käytettäessä. Meillä voidaan $500 \mathrm{ml}$ tilavuutta pitää tyydyttävänä (31).

\section{Kevätvehnä}

Kuten jo edellä viitattiin on kevätvehnän jalostuksessa riittävän aikaisuuden huomioonottaminen ratkaisevan tärkeä paitsi sadon saannin varmistamisen myös kvaliteetin kannalta. Niinpä on maamme kevätvehnän jalostuksessa kiinnitetty erityistä huomiota aikaisuuteen, ja kaikki tähän asti kasvinjalostuslaitoksiltamme kauppaan tulleet kevätvehnäjalosteet ovat tunnettua ja meillä kauan yleisesti viljeltyä Svalöfin Timantti-vehnää aikaisemmat.

Kun risteytysjalostustyöhön etsittiin lajikkeita, joissa kvaliteettigeenit olisivat voimakkaasti edustettuina, on Maatalouskoelaitoksen kasvinjalostusosastolla kiinnitetty erityistä huomiota kanadalaisiin ja amerikkalaisiin lajikkeihin. Aluksi käytettiin työhön varsinkin kuuluisaa kanadalaista Marquis-vehnää (Manitoba-vehnän valtalajike kauan aikaa). Tämä jaloste on Jokioisten Sopu- ja Hopea-vehnäin (kauppaan vuosina 1935 ja 1936) toisena vanhemmaislajikkeena, toisena on Tammiston Ruskea-kevätvehnä. Myös mm. Garnet(Granaatti-) ja Prelude-vehniä käytettiin risteytyksiin, ensinmainittu on toinen Jokioisten Apu-vehnän (kauppaan 1950) vanhemmaislajikkeista, toisena on Tammiston aikainen Pika-vehnä. Ruotsalaisista jalosteista käytettiin risteytyksiin aluksi varsinkin Kolben- ja Extra Kolben-vehniä, jotka ovat tunnetut hyvästä leivontakelpoisuudestaan, saksalaisista sikäläisten parhaimpiin kuuluvaa Janetzkys Früher-vehnää jne. 
Myös Tammiston jalostustyössä käytettiin hyväksi kanadalaisia jalosteita. Niinpä Tammi-vehnä (kauppaan 1938) polveutuu risteytyksestä, jonka toisena vanhemmaislajikkeena on kanadalainen, nimeltään tuntematon lajike. Tammiston Kimmo-vehnä taas polveutuu itäeurooppalaisesta kevätvehnästä.

Kun näkyi, että työssä oli päästy tuloksiin, oli luonnollista käyttää uusia jalosteita jatkuvaan jalostustyöhön. Varsinkin Hopea- ja Sopu-vehniä käytettiin risteytyksiin sekä Jokioisissa että Tammistossa. Hopea-vehnä on toisena vanhempana Jokioisten Touko- (kauppaan 1951) ja Tammiston Terä-vehnässä (kauppaan 1952). Touko-vehnän toisena vanhempana on Timantti-vehnä. Jokioisten Kiuru-vehnä (kauppaan 1952) taas rakentuu Sopu-vehnän ja Aurore-vehnän keskeiselle risteytykselle. Kaikissa näissä jalosteissa on siis isovanhemman Marquis-vehnän geenejä. Näistä lajikkeista on, Jokioisten kokeitten mukaan Apu 10 päivää, Sopu 7 päivää, Tammi 6 p., Kiuru ja Hopea 4 p., Kimmo 3 p., Terä 2 p. ja Touko 1 päivän Timanttia aikaisemmat. Kortensa lujuuden puolesta ovat Kiuru ja Apu Timantin kaltaisia, muut Timanttia jonkin verran tai selvästi lujakortisemmat.

Jokioisten kvaliteettijalostustyössä on kanadalaisia ja amerikkalaisia jalosteita jatkuvasti käytetty hyväksi suuressa mittakaavassa. Niistä on jälkeläisiin saatavissa paitsi kvaliteettigeenejä myös tautienkestävyysgeenejä (mm. Ceres, Thachter, Renown, Regent, Coronation, Redman, Rival, Cadet, Mida ym.). Varsinkin ruosteitten- ja nokienkestävyysjalostustyö on Kanadassa ja Yhdysvalloissa antanut kauniita tuloksia, joita nykyisin käytetään hyväksi vehnän jalostustyössä kaikkialla maailmassa.

Vehnän kvaliteetista l. leivontakelpoisu udesta puheen ollen tulee ensiksi vastattavaksi kysymys: millaista on hyvä vehnäleipä ja millaista se vehnäjauho, josta hyvää vehnäleipää saadaan? Vastaus tähän kysymykseen voi olla moninainen (vrt. mm. 16, 21), mutta eräät piirteet näyttävät olevan hyvälle vehnäjauholle ja vehnäleivälle varsin laajalti ja yleisesti hyväksyttyjä, nimittäin:

1. Jauholla on hyvä vedensitomiskyky.

2. Taikinasta saadaan tavallisin leivontamenetelmin kookas leipä.

3. Leivän sisus on tasaisesti verraten pienihuokoinen ja väriltään kellertävän valkoinen.

4. Leipä on terveellistä ja maukasta.

Tarkastamme aluksi mittarilajiketta, Svalöfin Timantti-vehnää, joka meillä on jo kohta parin vuosikymmenen ajan ollut kevätvehnän valtalajikkeena (taulukot 1-7). Pesola (9) on merkinnyt tälle lajikkeelle laatuarvon B-. Taulukoista ilmenee Timantin jyvän suhteellisen suuri proteiinipitoisuus sekä jauhon hyvä vedensitomiskyky. Proteiinipitoisuuden runsaus tekee Timantin kiitolliseksi kemikaliokäsittelylle. Timantin sitkoaineen laatu, mm. sen kestävyys on ainoastaan keskinkertainen, mikä näkyy sekä farinogrammin hyvyysluvuista että leivontakokeitten tuloksista. Kun Timantti on jo kauan ollut meillä runsaasti viljelyssä, on sen täytynyt varsin olennaisesti tuntua meidän leipäteollisuudessamme. Sikäli kuin asia on arvosteltavissa, on tulos merkittävä vähintään tyydyttäväksi. Åkermavin ym. katsauksista ilmenee, että lajike kvaliteetiltaan Ruotsissa selvästi ylittää ne melko korkeat normit, jotka on virallisesti asetettu kelvollisen kvaliteetin minimiksi. 
On ilmeistä, että Timantista ja vastaavaan aikaisuusluokkaan kuuluvista vehnistä Ruotsissa saadaan leivontaominaisuuksiltaan parempaa vehnää kuin meillä. Tämä kysymys ansaitsisi lähempää selvittelyä. Kun kevätvehnän viljely Ruotsissa tapahtuu huomattavasti etelämmässä kuin meillä, on todennäköistä, että mainittu ero johtuu ratkaisevasti ilmastollisista tekijöistä. Timanttia voidaan kuitenkin kasvuaikansa pituuden puolesta ja kvaliteettituotantoa ajatellen pitää etelä-Suomessa riittävän aikaisena lajikkeena. Leikkuupuimurin käyttöön sen suhteellinen myöhäisyys kuitenkin asettaa tietyt rajoitukset.

Sopu-, Tammi-, Hopea- ja Kimmo-vehnistä on rouhe- ja farinografituloksia runsaasti (taul. 1-4), mutta leivontatuloksia jossain määrin hajanaisesti, eri vuosilta ja eri paikoista, joten yhtenäistä, kokoavaa taulukkoa ei ole voitu laatia. Otamme näiden lajikkeitten laatua kuvaamaan otteen VEIJOLAn (27) julkaisemista taulukoista (taul. 1). Mainittu kesä 1939 oli sääsuhteiltaan kevätvehnän kvaliteettikasvatukseen erittäin suotuisa, joten lajikkeitten laatu esiintyy taulukossa normaalia parempana. Taulukon lukuja käytettäessä on lisäksi muistettava, että lajikkeista on ollut näytteitä tutkittavana eri suuret määrät ja että näytteet ovat koeasemilta.

Taulukosta ilmenee mm. jyväin proteiinipitoisuuden poikkeuksellinen suuruus, seurauksena kasvukauden olosuhteista. Huomattava on, että Hopea ja Sopu jäävät runsaitten tutkimusten mukaan proteiinipitoisuudessa - päinvastoin kuin taulukossa - Timantista jonkinverran tai selvästi jälkeen (mm. 25).

Sopu- ja Hopea-vehnäin jauhon vedensitomiskyky on pienempi kuin Timantin vastaava. Rouheluvut ja valorimetriluvut ovat paremmat kuin Timantin. Kumpikin antaa suuremman leivän kuin Timantti. Hopea-vehnän kestävyys, mikä näkyy $\mathrm{mm}$. kesto- ja valorimetriluvuista, on erittäin hyvä. VEIJOLA $(25,27)$ tutkimustensa perusteella korostaa Hopean arvoa sekotusvehnänä. Sopu ja Hopea ovat leivontaominaisuuksiltaan katsottava Timanttia paremmiksi. Aikaisemmassa esityksessään Pesola merkitsi ne kummatkin B + vehniksi. Hopea-vehnä voitaisiin sitkoaineensa laadun perusteella ehkä varustaa merkillä $\mathrm{A}$ - .

Tammi-vehnällä on, useiden tutkimusten mukaan, vielä suurempi proteiinipitoisuus kuin Timantilla, ja sen rouhe- ja valorimetriluvut ovat suuremmat kuin Timantin. Leivontatulosten puolesta Tammi kuitenkin jäänee Timantin luokkaan (B-). VEIJoLAn (24) mukaan Tammen käyttöarvoa vähentää jauhon värin harmahtavuus ja jauhatusominaisuuksiin vaikuttava jyvän pehmeys.

Kimmo-vehnän laatutuloksia esitetään taulukoissa 1, 3 ja 4. Kimmo-vehnällä on erittäin korkeat rouhe- ja valorimetriluvut, merkkinä jauhon ja siitä valmistetun taikinan erikoisesta kimmoisuudesta ja kestävyydestä. Kimmon proteiinipitoisuus näyttää olevan Timantin korkeata luokkaa. Vedensitomiskyvyssä ei Kimmo kuitenkaan pääse Timantin tasoille. V:n 1939 sadosta leivottu Kimmo antoi tilavuudeltaan erinomaisen tuloksen. V:en 1939 mennessä Kimmosta suoritettujen tutkimusten mukaan Veijola (27) mainitsee Kimmon meillä silloin viljellyistä kevätvehnälajikkeista parhaaksi ja sellaisenaan erittäin arvokkaaksi. Myöhemmiltä vuosilta Kimmosta on niukanlaisesti tutkimustuloksia. Eräistä Ylistaron koeasemalla kasvaneesta aineistosta suoritetuista tutkimuksista ilmenee, että Kimmon leivontatulokset täällä ovat keskimäärin vain Timantin luokkaa (taul. 4). Kimmon var- 
sin vaatimattomat leivontatulokset Ylistarosta kiinnittävät huomiota erityisesti mm. sen vuoksi, että Kimmoa on nimenomaan laatuvehnänä suositeltu juuri EteläPohjanmaalle, jonka alueen suotuisimmille paikoille sen pitäisi kasvuaikansa puolesta soveltuakin. Kimmo-vehnän asemaa asteikossa $\mathrm{A}-\mathrm{C}$ täytynee toistaiseksi pitää epävarmana. Mahdollisesti se on luettava, Hopea-vehnän tavoin, luokkaan A—, tai kenties sen olisi tyydyttävä luokkaan $\mathrm{B}+$. Kimmon jyvän suhteellista pienuutta pitänevät myllymiehet sille epäetuna.

Jokioisten uusimmista jalosteista näyttävät Touko ja Kiuru (taulukko 5) olevan leivontaominaisuuksiltaan hiukan - jonkinverran Timanttia paremmat (B tai B+). Apu-vehnä sensijaan (taulukko 6) jäänee Timantin luokkaan (B-). Tammiston uudesta Terä-vehnästä (taulukko 5) on toistaiseksi niukanlaisesti tutkimustuloksia. Näyttää siltä että Terä $(\mathrm{B}+)$ olisi leivontaominaisuuksiltaan selvästi Timanttia parempi, mutta ei kuitenkaan Kimmon ja Hopean luokkaa.

Edellä esitetystä ilmenee, että kasvinjalostajat ovat varsin huomattavassa määrin onnistuneet yrityksissään parantaa kevätvehnämme leivontakelpoisuutta. Lajikesarja Kimmo, Hopea, Sopu, Tammi, Terä, Touko, Kiuru ja Apu osoittaa nämä saavutukset varsin vakuuttavasti. Samalla ilmenee, että kanadalaisten laatuvehnäin Marquis ja Garnet käyttäminen tässä jalostustyössä on ollut varsin merkityksellistä.

Edellä on tullut viitatuksi myös mainittujen jalosteitten eräisiin viljelyominaisuuksiin,'nimenomaan niiden aikaisuuteen ja korren lujuuteen. Yksityiskohtiin menemättä mainittakoon, että nämä jalosteet ovat myös muilta viljelyominaisuuksiltaan, nimenomaan satoisuudeltaan varsin arvokkaat viljeltäviksi niissä osissa maatamme, minne ne on tarkoitettu.

Mainittakoon vielä lyhyesti eräitten meillä huomionarvoisten, Timanttia uudempien ruotsalaisten kevätvehnälajikkeiden leivontakelpoisuudesta.

Maamme eteläosiin on useina viime vuosina Timantin tilalle tai sen rinnalle melkoisesti levinnyt Svalöfin Timantti II (taulukot 1 ja 5). Timantti II:n jyvässä on hiukan vähemmän proteiinia ja sitkoainetta kuin Timantin jyvässä, mutta sitkoaine on laadultaan parempaa $(\mathrm{B}+)$. Jauhonparannusaineita käytettäessä ero näyttää lähes häviävän (vrt. 15).

Kärni (Kärn II, taulukot 5 ja 7)-vehnää pidetään Ruotsissa leivontaominaisuuksiltaan varsin arvokkaana. Meillä suoritetuissa tutkimuksissa on huomio kiintynyt Kärnin valorimetriluvun suhteelliseen suuruuteen. Leivontakokeen tulokset näyttävät viittaavan siihen, että Kärni olisi meillä viljeltynä leivontaominaisuuksiltaan jonkinverran Timanttia parempi, ehkäpä Timantti II:n luokkaa (B+). Tässä kohden on kuitenkin huomattava, että tutkimuksiin käytetty aineisto on saatu kasvinjalostus- ja koelaitoksilta, suurella huolella ja valppaudella käsitellystä viljelyaineistosta. Käytännön kokemukset näyttävät viittaavan siihen, että Kärnistä yleensä tuskin saadaan käytännön viljelyksiltä leivontaominaisuuksiltaan näin edullista viljaa. - On mielenkiintoista tietää, että myös Sveitsissä ovat Kärnin leivontakelpoisuuskokemukset vähemmän edulliset kuin Ruotsista saadut (10).

Uusimmasta ruotsalaisesta tulokkaasta, Weibullsholmin Svenno-vehnästä on 
meillä toistaiseksi niukalti kvaliteettiin kohdistuvia tutkimustuloksia (taulukko 7). Ne näyttävät viittaavan siihen, että Svenno on leivontaominaisuuksiltaan vähemmän arvokas kuin Kärni ja Timantti II, ehkäpä vain Timantin luokkaan (B-) luettava.

Kärni-vehnä on Jokioisten useampivuotisissa kokeissa ollut viitisen päivää ja Svenno kolmisen päivää Timanttia myöhäisempi, mikä seikka on niille epäeduksi kvaliteettiviljelyä ajatellen. Kärni on jonkinverran ja Svenno selvästi Timanttia lujakortisempi. Niiden erinomainen satoisuus vaikuttaa, että niitä voidaan suositella maan eteläosiin ilmastollisesti kaikkein suotuisimpiin paikkoihin, missä niiden myöhäisyys ei kovin pahasti vaaranna sadon käyttöarvoa.

\section{Syysvehnä}

Kuten jo edellä mainittiin kohdistettiin kotimaisen jalostustyön alkuvaiheissa, jolloin kvaliteettia ei vielä otettu lukuun, suuri huomio maatiaisvehniin ja niistä otettuihin linjoihin. Niiden talvenkestävyys oli yleensä hyvä tai erinomainen, mutta ne olivat yleensä heikko-olkisia ja ruosteitten arkoja. Tällaisen linjajalostustyön tuloksena laski Tammisto kauppaan mm. Sukkula-vehnänsä (I ja II), jotka aikanaan saavuttivat meillä suhteellisen runsaan levikin. Jokioisista laskettiin kauppaan maatiaisvehnästä polveutuva Pohjola-vehnä, joka oli varsin kelvollinen viljelyominaisuuksiltaan ja keskimääräisestä ilmeinen plus-poikkeama leivontaominaisuuksiltaan (vrt. mm. 25).

Mutta yleensä runsas maatiaisvehnäaineisto jalostustyön kestäessä heikkouksiensa vuoksi karsiutui. Oli oikeastaan vain sattuma, että niiden harvain maatiaislinjain joukossa, jotka teoreettisten tai käytännöllisten töiden vuoksi Jokioisten laitoksessa säilytettiin, oli sellainen leivontaominaisuuksiltaan oivallinen linja, jollaiseksi Jo 08409, sittemmin Olympiaksi nimetty (kauppaan 1941) osoittautui. Olympiasta on runsaasti rouhe- ja farinografituloksia (taul. 8-10), mutta leivontatuloksia niukemmin, eikä niitä helposti voi yhdistää samaan taulukkoon (2-vuotiset tulokset taul. 8). Nämä tutkimukset, runsaan käytännön kokemuksen tukemina näyttävät osoittavan, että Olympia on leivontaominaisuuksiltaan erittäin arvokas. VEIJOLA (27) pitää Olympiaa leivontaominaisuuksiltaan parhaiden kotimaisten kevätvehnäin (siis Kimmon ja Hopean) veroisena. Olympia-vehnälle on tunnusomaista proteiinin runsaus ja sitkoaineen sekä runsaus että hyvä laatu. Verrattuna Varma-vehnään, joka leivontaominaisuuksiltaan lähenee Timanttia, Olympia antaa tuntuvasti suuremman leivän ja se reagoi verraten herkästi parannusaineille. PEsola (9) on merkinnyt Olympian kuuluvaksi ryhmään $\mathrm{B}+$, mutta mahdollisesti Olympia voidaan viedä ryhmään $\mathrm{A}$ - Sillä on huomattava sekotusarvo. Olympian kvaliteetti saattaa kuitenkin vaarantua sen kautta, että lajike verraten helposti lakoutuu, jotapaitsi sitä usein viljellään puolikesantomaassa, siis heikohkoissa viljelyolosuhteissa, joissa useimmiten ei saada kvaliteetiltaan parasta mahdollista vehnää.

Luonnollisesti on Olympia-vehnää runsaasti käytetty riste y t y s j a l o st u s t y ös sä, nimenomaan kvaliteettia silmällä pitäen. Samassa tarkoituksessa on risteytyksiin laajassa mittakaavassa käytetty eräitä amerikkalaisia, »hard red 
winter»-tyyppiin kuuluvia lajikkeita varsinkin Kharkof- ja Turkey-lajikkeita (molemmat alkuaan Venäjältä), samoin Kanred-, Minhardi-, Minturki- ym. vehniä. Osoittautui kuitenkin, että täten saatiin jälkeläispolviin geenejä, jotka eräitä tärkeitä viljelyominaisuuksia, erityisesti ominaissatoisuutta ajatellen, eivät olleet toivottuja.

Myös ruotsalaisia (Svalöfin ja Weibullsholmin) jalosteita on suuressa määrin käytetty risteytyksiin. Kuluvan vuosisadan alkupuolella Ruotsin syysvehnänjalostus rakentui suureksi osaksi englantilaiselle squarehead-vehnälle. Tästä saatiin nimenomaan hyviä ominaissatoisuuden ja korren lujuuden geenejä, mutta talvenkestävyydessä jouduttiin tinkimään. Ominaista squarehead-vehnälle oli lisäksi leivontaominaisuuksien heikkous; nämä vehnät olivat ja ovat tyypillistä heikkoa (pehmeää) vehnää. Tämä squarehead-vehnän vaikutus tuntui kauan aikaa ruotsalaisessa syysvehnänjalostustyössä, vehnän laatua huonontaen, ja se tuntuu edelleen (vrt. mm.34). Tämän vuoksi ruotsalaiset jalosteet eivät yleensä ole olleet syysvehnän jalostustyössä kiitollisia kvaliteettia ajatellen. Mm. Jokioisten Sampo ja Tammiston Panu ovat osoituksia tästä.

Kvaliteettijalostuksessa käytettiin hyväksi myös eräitä laadultaan ja muutenkin arvokkaiksi osoittautuneita vi rola is i a jalosteita. Eräs tällainen saatiin Kehran kasvinjalostuslaitokselta ja se on sen jälkeen Jokioisissa kulkenut Kehranimisenä. Kehran ja Varma-vehnän risteytyksestä polveutuu Jokioisten Vakkavehnä, joka viime vuonna tuli kauppaan (vrt. 11).

Taulukoissa 8-10 esitellään Tammiston vanhan Varma-vehnän (Svea $\times$ maatiainen, kauppaan 1933) ja Vakka-vehnän laatua koskevia tutkimustuloksia. Varman jyvässä on suhteellisen runsaasti proteiinia, ja jauhon vedensitomiskyky on varsin suuri. Varman sitkoaineen laatu on kuitenkin heikonlainen, varsinkin sen kestävyys on vähäinen. Leivontakokeissa ilmenee, että Varman leipätilavuus on yleensä korkeintaan keskinkertainen. Pesola (9) vei aikanaan Varman ryhmään $\mathrm{C}+$. Ehkäpä voitaisiin Varma, kokonaiskäyttöarvoltaan, lukea ryhmään B-, siis samaan kuin Timantti.

Vakka-vehnän jyvissä on jonkinverran vähemmän proteiinia kuin Varman jyvissä. Mutta rouheluku ja valorimetriluku ovat huomattavan korkeat, ilmaisten sitkoaineen hyvän kimmoisuuden ja kestävyyden. Jauhon vedensitomiskyky on hiukan pienempi kuin Varman, mutta leipätilavuus on selvästi suurempi ja sellaisenaan huomattavan korkea. Tähän astisten tutkimusten mukaan voitaneen Vakka leivontakelpoisuudeltaan lukea hyvien kevätvehnien (Terä, Sopu) laatuluokkaan $(\mathrm{B}+)$. Vakan erikoinen aikaisuus ja lujakortisuus ovat omiaan varmistamaan sen arvoa kvaliteettivehnänä, mutta Vakan ilmeinen idältymisherkkyys saattaa sen vaarantaa.

Ruotsalaisista syysvehnäjalosteista ovat tähän mennessä ainoastaan Jarl ja Virtus (molemmat Weibullsholmista) osoittautuneet viljelyominaisuuksiltaan, nimenomaan talvenkestävyydeltään meillä huomionarvoisiksi. Suoritetut kvaliteettitutkimukset (29) ovat osoittaneet ne leivontaominaisuuksiltaan heikoiksi (C-resp. C). Niitä on meillä jonkinverran viljelty ja viljellään keksiteollisuuden tarpeeksi. Ruotsin syysvehnäjalosteiden joukossa on kuitenkin kvaliteetiltaan parempiakin $(32,33)$. 
Kotimaisessa syysvehnän kvaliteettijalostuksessa voitaneen Olympia- ja Vakkavehnäin aikaansaamista pitää merkittävänä edistysaskeleena. Sikäli kuin on tunnettua ei pohjois- ja keski-Euroopassa viljeltyjen syysvehnälajikkeitten joukossa ole tähän mennessä ollut leivontaominaisuuksiltaan Olympiaa voittanutta lajiketta.

\section{Jauhatus-(myllytys-)ominaisundet}

Kiinnitettäköön vielä huomiota myös vehnäin jauhatus-(myllytys-)ominaisuuksiin (kirjallisuudesta ks. esim. 18). Pohjoismaissa on S. O. BERG (1) ensimmäisenä kytkenyt jauhatusominaisuudet systemaattisesti jalostustyöhön, ja F. FAJERSSON (2) on jatkanut tätä työtä. Berg on luonut käsitteen "örighet» (»rakeisuus»), ja hän määrittelee rakeisen jauhon seuraavasti: rakeisella jauholla tarkoitetaan sellaista, joka on helposti "valuvaa", ja on vailla taipumusta kokkaremuodostukseen. Rakeinen jauho tuntuu sormissa "hiekkamaiselta" vastakohtana "sileille» jauhoille. Berg on tullut siihen tulokseen, että tämä ominaisuus johtuu osaksi myös perinnöllisistä tekijöistä ja kuuluu siten läheisesti kasvinjalostajan työ- ja harrastuspiiriin. Bergin luoma, Ruotsissa runsaasti viljelty Eroica (I ja II) vehnä antaa jauhettaessa rakeista jauhoa. Yleisen tavan mukaan sanotaan vehniä, jotka jauhettaessa antavat pääasiallisesti rakeista jauhoa, koviksi ja niitä vehniä, jotka jauhettaessa antavat pääasiallisesti "sileätä» jauhoa, pehmeiksi. Ensinmainituille on jyväin runsas lasimaisuus ominaista. Myllyteknillisesti ovat edelliset jälkimmäisiä arvokkaammat.

Tietääksemme ei m e illä ole jalostustyön yhteydessä tai muuten suoritettu tutkimuksia tämän kysymyksen alalta. Jokioisissa on kuitenkin jo usean vuoden aikana koejauhatuksen aikana pidetty näitä asioita silmällä ja tehty niistä muistiinpanoja. Samoin on menetelty myös Valtion teknillisessä tutkimuslaitoksessa. Vehnälajikkeista, joita myllyt ovat saaneet riittävän suurina ja yhtenäisinä erinä, on myllyille tietenkin kertynyt runsaasti näitä seikkoja koskevia käytännön kokemuksia. Meillä on Pulkk (14) tutkimuksillaan selvitellyt vehnän erilaisen hienouden tai karkeuden merkitystä vehnän leivontaominaisuuksiin sekä (17) jauhon ja ilman suhteellisen kosteuden merkitystä jauhatusprosessiin.

Sikäli kuin tähän mennessä tiedetään voidaan meillä nykyisin viljeltyjen tärkeimpien vehnälajikkeitten jauhatusominaisuuksista sanoa seuraavaa:

Kevätvehnät ovat - tietyin vivahduksin — kaikki kovia vehniä, lukuunottamatta Tammi-vehnää, joka on melko tyypillistä pehmeätä vehnää.. ${ }^{1}$ Vanha Timantti on erityisen luonteenomaista kovaa vehnää, mikä osaltaan varmaan on vaikuttanut sen saamaan suosioon.

Syysvehnästä on Varma tyypillistä kovaa vehnää, mikä seikka on tehnyt sen myllyteollisuudessa suosituksi. Vakka näyttää tässä suhteessa suuresti muistuttavan Varmaa, toista vanhemmaislajikettansa. Olympia on kai luettava puolikoviin vehniin. Luonteenomaisia pehmeitä vehniä ovat vanhat kotimaiset jalosteet kuten Sampo ja Panu, kuten ilmeisesti myös uusi tulokas Okey, samoinkuin edellä mainitut Jarl- ja Virtus-vehnät.

1 Terä kuulunee myös tähän ryhmään. 
$Y$ h t e e nve to n a edellä esitetystä voidaan mainita seuraavaa:

S y y s v e hnä st ä on maassamme käytettävissä, kotimaisen kasvinjalostustyön tuloksena, lajikkeita (Varma, Olympia, Vakka), jotka leivontaominaisuuksiltaan (Olympia, Vakka) ja jauhatusominaisuuksiltaan (Varma, Vakka) täyttävät varsin tai erittäin korkeat vaatimukset. Syysvehnän aikainen tuleentuminen on omiaan varmistamaan sadon laadun hyvyyden, lakoutuneisuus ja loppukesän sateisuus saattaa sitä vaarantaa. Varmalla ja Olympialla on tiettyjä viljelybiologisia heikkouksia, jotka rajoittavat niiden viljelyä; Vakkaan kiinnitetään toiveita. Syysvehnän jalostustyössä vaativat vehnän jauhatusominaisuudet osakseen ilmeisesti entistä suurempaa huomiota.

K e vä t v e h n ä s t ä on käytettävissä olevalla lajikevalikoimalla sen laatutaso pidettävissä tyydyttävällä korkeudella. Kotimaisessa jalostustyössä on varsin edullisesti onnistuttu yhdistämään sovelias aikaisuus ja hyvät leivontaominaisuudet (B tai lähes A luokka). Ruotsalaisilla jalosteilla on, niiden monien edullisten viljelyominaisuuksien ohessa suhteellinen myöhäisyys haittana, nimenomaan kvaliteettituotantoa ajatellen. Kevätvehnän viljelyssä meillä on kiinnitettävä erityistä huomiota lajikkeitten aikaisuuteen, ja kullekin viljelyalueelle on koetettava saada aikaisuuden puolesta soveliaat lajikkeet.

Vehnän lajiketilanne on meillä nykyisin sellainen, että sääsuhteiltaan normaalisina ja normaalista edullisempina kesinä voimme itse tuottaa laadultaan tyydyttävän vehnäviljan. Sääsuhteiltaan epäedulliset kesät (koleus, sateisuus, hallaisuus ym.) vaikuttavat erityisesti kevätvehnän kvaliteettiin. Tästä syystä ja syysvehnän suhteellisen runsaan satoisuuden vuoksi olisi erityisesti syysvehnän viljelyä lisättävä.

Vehnälajikkeittemme suhteellisen korkea kvaliteettitaso on tärkeätä ottaa huomioon pyrittäessä vehnäntuotannossa omavaraisuutta kohti ja järjestettäessä vehnäviljan tuontia ulkomailta. Vehnän hyvällä kvaliteetilla on huomattava kansantaloudellinen merkitys. 
Taulukot. - The tables.

Taulukko 1. Eräiden kevätvehnälajikkeiden leivontakelpoisuus v. 1939 Valtion teknillisessä tutkimuslaitoksessa (lyhennettynä V.t.t.) suoritettujen määritysten mukaan.

Table 1. Baking quality of some varieties of spring wheat in 1939, according to determinations carried out at the State Technical Research Institute (abbr. T.R.I.).

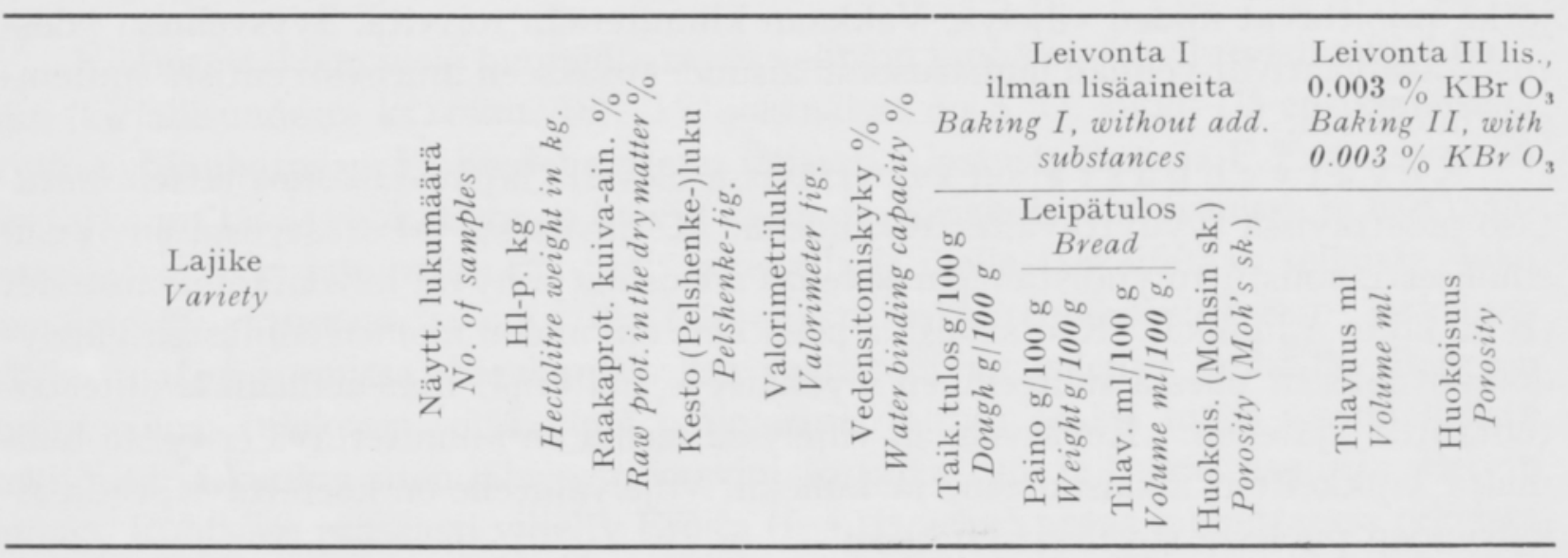

\begin{tabular}{|c|c|c|c|c|c|c|c|c|c|c|c|}
\hline ti (Diamend), Svali & 11 & 80.7 & 15.6 & 36 & 7.9 & 63.2 & 168 & 141 & 539 & 7.3 & 97 \\
\hline Timantti II (Diam. II), & 7 & 82.2 & 15.3 & 51 & 72.0 & 61.4 & 165 & 137 & 640 & 7.1 & 716 \\
\hline Sopu, Jokioinen & 8 & 80.0 & 15.8 & 68 & 69.9 & 62.5 & 166 & 141 & 605 & 6.6 & 698 \\
\hline Hopea, Jokioiner & 5 & 82.0 & 16.6 & 113 & 79.4 & 62.5 & 165 & 140 & 627 & 6.3 & 719 \\
\hline Tammi, Tam & - & 80.0 & 16.8 & 60 & 7.1 & 58.7 & 162 & 135 & 550 & 6.1 & 628 \\
\hline Kimmo, Tammisto & 5 & 82.9 & 15.8 & 127 & 90.0 & 57.3 & 161 & 135 & 697 & 5.8 & 829 \\
\hline
\end{tabular}

Taulukko 2. Sopu- ja Hopea-kevätvehnäin valorimetriluvut ja vedensitomiskyky ( $\%)(6 \mathrm{v}$.).

Table 2. Valormeter figures and capacity of binding water (\%) for the spring wheat varieties Sopu and Hopea at Jokioinen (6 years).

\begin{tabular}{lllllllll}
\hline $\begin{array}{l}\text { Lajike } \\
\text { Variety }\end{array}$ & 1937 & 1938 & 1940 & $1942^{1}$ & 1947 & 1952 & $\begin{array}{c}\text { Keskim. } \\
\text { Aver. }\end{array}$ \\
\hline
\end{tabular}

Valorimetriluvut

Valorimeterfig.

$\begin{array}{llllllll}\text { Timantti (Diam.) } & 51 & 59 & 62 & 52 & 57 & 47 & 54.7 \\ \text { Sopu } & 56 & 59 & 61 & 57 & 58 & 52 & 57.2 \\ \text { Hopea } & 58 & 63 & 63 & 60 & 63 & 52 & 59.8\end{array}$

Vedensitomiskyky

Capacity of bind. wat.

$\begin{array}{llllllll}\text { Timantti (Diam.) } & 59.1 & 63.8 & 57.2 & 65.4 & 62.4 & 62.8 & 61.8 \\ \text { Sopu } & 57.3 & 62.4 & 58.9 & 64.5 & 62.7 & 62.5 & 61.4 \\ \text { Hopea } & 56.1 & 60.4 & 59.7 & 63.5 & 61.7 & 61.7 & 60.5\end{array}$

1 Veijola (29) 
Taulukko 3. Eräiden kevät- ja syysvehnälajikkeiden kestoluvut keskim. vv. 1946_-1952 (7v.) Maatalouskoelaitoksen kasvinjalostusosastolla Jokioisissa suoritettujen määritysten mukaan.

Table 3. Average "Testzahl" (Pelshenke) figures for some varieties of spring and winter wheat in $1946-1952$ (7 years) according to determinations carried out at the Agricultural Research Centre, Department of Plant Breeding, Jokioinen.

\begin{tabular}{cc}
\hline Lajike & Kesto-1. Pelsh.1. \\
Variety & Pelshenke fig. \\
\hline
\end{tabular}

Kevätvehnä

Spring wheat

Timantti (Diam.) Sval. $\quad 37$

Sopu, Jok. $\quad 56$

Hopea, Jok. 83

Tammi, Tamm. $\quad 49$

Kimmo, Tamm. 65

Kiuru, Jok. $\quad 54$

Touko, Jok. $\quad 43$

Apu, Jok. (45) (3 v. 1950-1952)

Syysvehnä

Winter wheat

Varma, Tamm. $\quad 37$

Olympia, Jok. $\quad 65$

Vakka, Jok. $\quad 61$

Virtus, Weib. 41

Taulukko 4. Tammi- ja Kimmo-kevätvehnäin leivontakelpoisuus verrattuna Timantti-vehnään (V.t.t.).

Tabel 4. Baking quality of the spring wheat varieties Tammi and Kimmo as compared with Diamond wheat (T.R.I.).

\begin{tabular}{|c|c|c|c|c|c|c|c|c|c|c|}
\hline \multirow[b]{3}{*}{$\begin{array}{l}\text { Lajike } \\
\text { Variety }\end{array}$} & \multirow{3}{*}{ 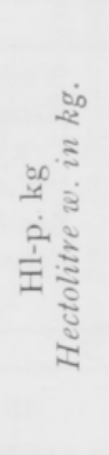 } & \multirow{3}{*}{ 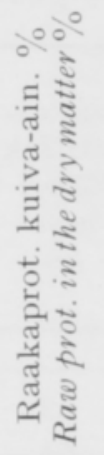 } & \multirow{3}{*}{ 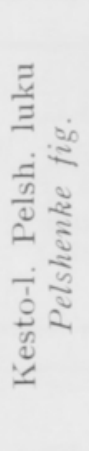 } & \multirow{3}{*}{ 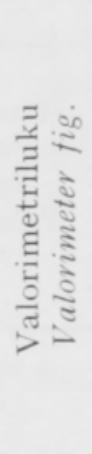 } & \multirow{3}{*}{ 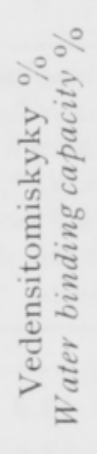 } & \multicolumn{5}{|c|}{$\begin{array}{c}\text { Leipätulos } \\
\text { Bread }\end{array}$} \\
\hline & & & & & & \multirow[b]{2}{*}{ 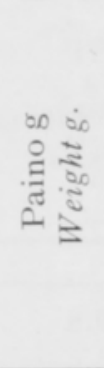 } & \multicolumn{2}{|c|}{$\begin{array}{c}\text { Leivonta I } \\
\text { Baking I }\end{array}$} & \multicolumn{2}{|c|}{$\begin{array}{c}\text { Leivonta II } \\
\text { Baking II }\end{array}$} \\
\hline & & & & & & & $\begin{array}{l}\vec{\Xi} \\
\vec{\Xi} \\
\vec{\Xi}\end{array}$ & 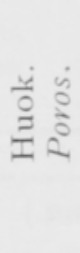 & $\begin{array}{l}\bar{\Xi} \cong \\
\dot{\Xi} \\
\stackrel{\vec{\Xi}}{\Xi} \\
\ddot{E}\end{array}$ & 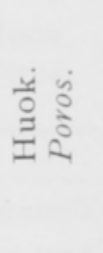 \\
\hline \multicolumn{11}{|c|}{ V. $194 \pi-48$ jа 1952 (3 v.). } \\
\hline Timantti (Diam.) & 79.6 & 14.2 & 40 & 50 & 67.0 & 143 & 455 & 7.5 & 505 & 7.8 \\
\hline Tammi & 78.9 & 14.8 & 57 & 58 & 61.1 & 141 & 410 & 6.8 & 495 & 6.5 \\
\hline \multicolumn{11}{|l|}{ V. $1947,1950,1952(3 v)}$. \\
\hline Timantti (Diam.) & 78.4 & 14.3 & 38 & 56 & 66.6 & 142 & 480 & 7.3 & 566 & 7.8 \\
\hline Kimmo & 80.7 & 14.5 & 106 & 86 & 61.4 & 141 & 493 & 7.0 & 533 & 6.8 \\
\hline
\end{tabular}


Taulukko 5. Timantti-, Timantti II-, Kärni-, Touko-, Kiuru- ja Terä-kevätvehnäin leivontakelpoisuus vv. $1947-1952$ (V.t.t.).

Table 5. Baking quality of the spring wheat varieties Diamond, Diamond II, Kärn II, Touko, Kiuru, and Terä in 1947-1952 (T.R.I.).

\begin{tabular}{|c|c|c|c|c|c|c|c|c|c|c|c|}
\hline \multirow{3}{*}{$\begin{array}{l}\text { Lajike } \\
\text { Variety }\end{array}$} & \multirow{3}{*}{ 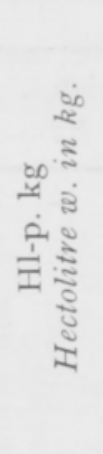 } & \multirow{3}{*}{ 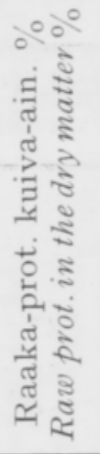 } & \multirow{3}{*}{ 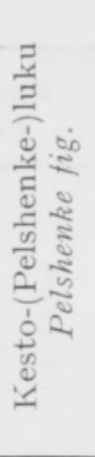 } & \multirow{3}{*}{ 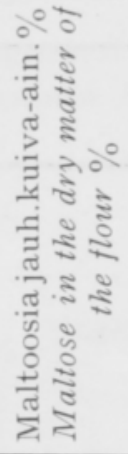 } & \multirow{3}{*}{ 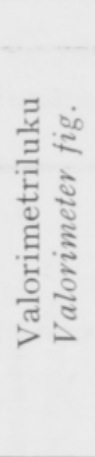 } & \multirow{3}{*}{ 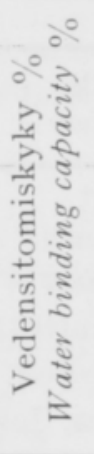 } & \multicolumn{5}{|c|}{$\begin{array}{c}\text { Leipätulos } \\
\text { Bread }\end{array}$} \\
\hline & & & & & & & \multirow{2}{*}{ 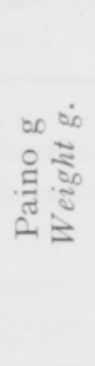 } & \multicolumn{2}{|c|}{$\begin{array}{l}\text { Leivonta I } \\
\text { Baking I }\end{array}$} & \multicolumn{2}{|c|}{$\begin{array}{c}\text { Leivonta II } \\
\text { Baking } I I\end{array}$} \\
\hline & & & & & & & & $\begin{array}{l}\bar{\Xi} \cong \\
\dot{\Xi} \Xi \\
\vec{\Xi}=\end{array}$ & $\begin{array}{l}\ddot{0} \dot{0} \\
\stackrel{0}{\Xi} \\
=2\end{array}$ & 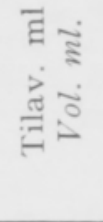 & 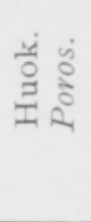 \\
\hline Timantti (Diam.) & 81.3 & 14.3 & 43 & 3.14 & 55 & 66.4 & 142 & 477 & 7.8 & 499 & 7.5 \\
\hline Timantti II (Diam. II) & 81.4 & 13.8 & 51 & 3.32 & 57 & 65.4 & 141 & 503 & 7.7 & 536 & 8.1 \\
\hline Kärni (Kärn II), Weib. & 81.9 & 13.3 & 65 & 3.16 & 66 & 61.1 & 138 & 492 & 5.8 & 539 & 6.6 \\
\hline Touko & 81.2 & 13.9 & 51 & 3.24 & 58 & 65.1 & 141 & 494 & 7.2 & 556 & 7.3 \\
\hline Kiuru & 81.7 & 13.6 & 75 & 3.75 & 61 & 66.4 & 144 & 489 & 7.2 & 526 & 7.7 \\
\hline Terä ${ }^{1}$, Tamm. & 80.5 & 13.8 & 100 & 3.18 & 61 & 65.7 & 143 & 488 & 7.8 & 548 & 7.3 \\
\hline Timantti (Diam.), vastaava & 80.8 & 14.5 & 45 & 2.74 & 58 & 65.4 & 143 & 472 & 7.8 & 499 & 7.9 \\
\hline
\end{tabular}

1 Tamm. 1947, Tikk. 1948, Tamm. 1950, Jok. 1950. Tamm. 1952, Jok. 1952 (6 tutk.) muut: Tikk. 1947, Jok. 1948, Jok. 1949, Jok. 1950, Tikk. 1951, Jok. 1952 (6 tutk.).

Taulukko 6. Apu-kevätvehnän leivontakelpoisuus verrattuna Timantti-vehnään VE1JOLAn (1950) mukaan v. 1945-47.

Table 6. Baking quality of the spring wheat Apu as compared to Diamond according to VEIJOLA (1950) in $1947-1952$.

\begin{tabular}{|c|c|c|c|c|c|c|c|}
\hline \multirow[b]{2}{*}{$\begin{array}{l}\text { Lajike } \\
\text { Variety }\end{array}$} & \multirow[b]{2}{*}{$\begin{array}{l}\text { Hl-p. } \\
\text { kg } \\
\text { Hectolitre } \\
\text { w. in kg. }\end{array}$} & \multirow{2}{*}{$\begin{array}{l}\text { Raaka- } \\
\text { prot. } \\
\text { kuiva- } \\
\text { ain. \% } \\
\text { Raw prot. } \\
\text { in the dry } \\
\text { matter \% }\end{array}$} & \multirow{2}{*}{$\begin{array}{l}\text { Kesto-1. } \\
\text { Pelsh. } \\
\text { luku } \\
\text { Pelshenke } \\
\text { fig. }\end{array}$} & \multirow{2}{*}{$\begin{array}{l}\text { Valori- } \\
\text { metriluku } \\
\text { Valori- } \\
\text { meter } \\
\text { fig. }\end{array}$} & \multirow{2}{*}{$\begin{array}{c}\text { Veden- } \\
\text { sitomis- } \\
\text { kyky \% } \\
\text { Water } \\
\text { binding } \\
\text { capacity } \\
\%\end{array}$} & \multicolumn{2}{|c|}{$\begin{array}{l}\text { Leipätulos } \\
\text { Bread }\end{array}$} \\
\hline & & & & & & $\begin{array}{c}\text { Paino } \\
\text { g } \\
\text { Weight } \\
\text { g. }\end{array}$ & $\begin{array}{c}\text { Tilav. } \\
\text { ml } \\
\text { Vol. } \\
\text { ml. }\end{array}$ \\
\hline Timantti (Diam.) & 80.8 & 13.9 & 44 & 53 & 65.6 & 144 & 494 \\
\hline $\mathrm{Apu}$ & 77.5 & 13.5 & 50 & 54 & 62.9 & 143 & 496 \\
\hline
\end{tabular}


Taulukko 7. Svenno-, Kärni- ja Timantti II-kevätvehnäin leivontakelpoisuus verrattuna Timanttivehnään vv. 1950 ja 1952 (V. 1950 Tikkurilan ja Tammiston sadosta, v. 1952 Jokioisten ja Tammiston sadosta, siis 4 tutk.). V.t.t.

Table 7. Baking quality of the spring wheat varieties Svenno, Kärn II, and Diamond II as compared to Diamond in 1950 and in 1952. (In 1950 from the yields of Tikkurila and Tammisto, in 1952 from the yields of Jokioinen and Tammisto, total 4 investigations). T.R.I.

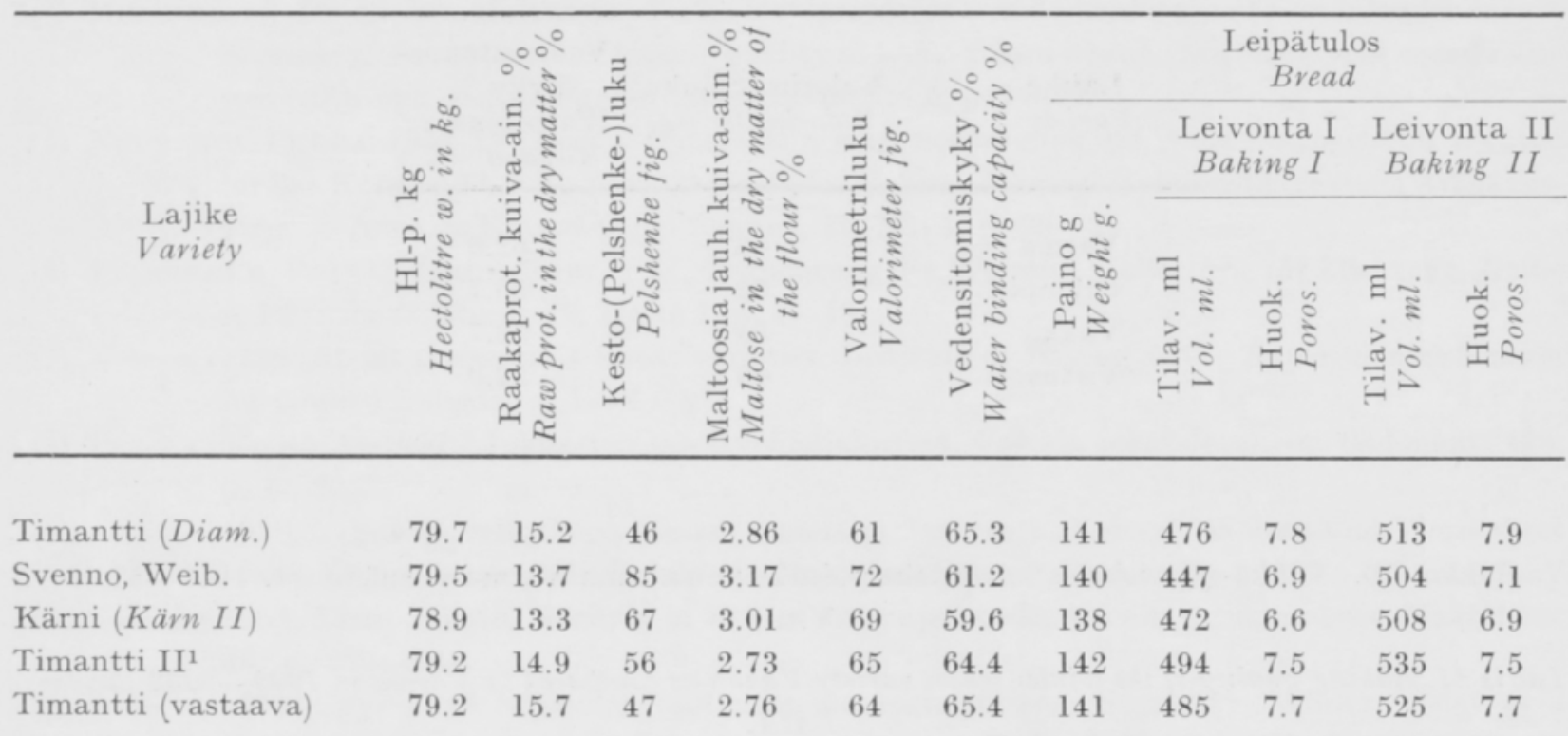

1 Tikk. 1950, Tamm. 1950, Jok. 1952 (3 tutk.).

Taulukko 8. Olympia- ja Virtus-syysvehnäin leivontakelpoisuus verrattuna Varma-vehnään. (V.t.t.). Table 8. Baking quality of the winter wheat varieties Olympia and Virtus as compared to Varma (T.R.I.).

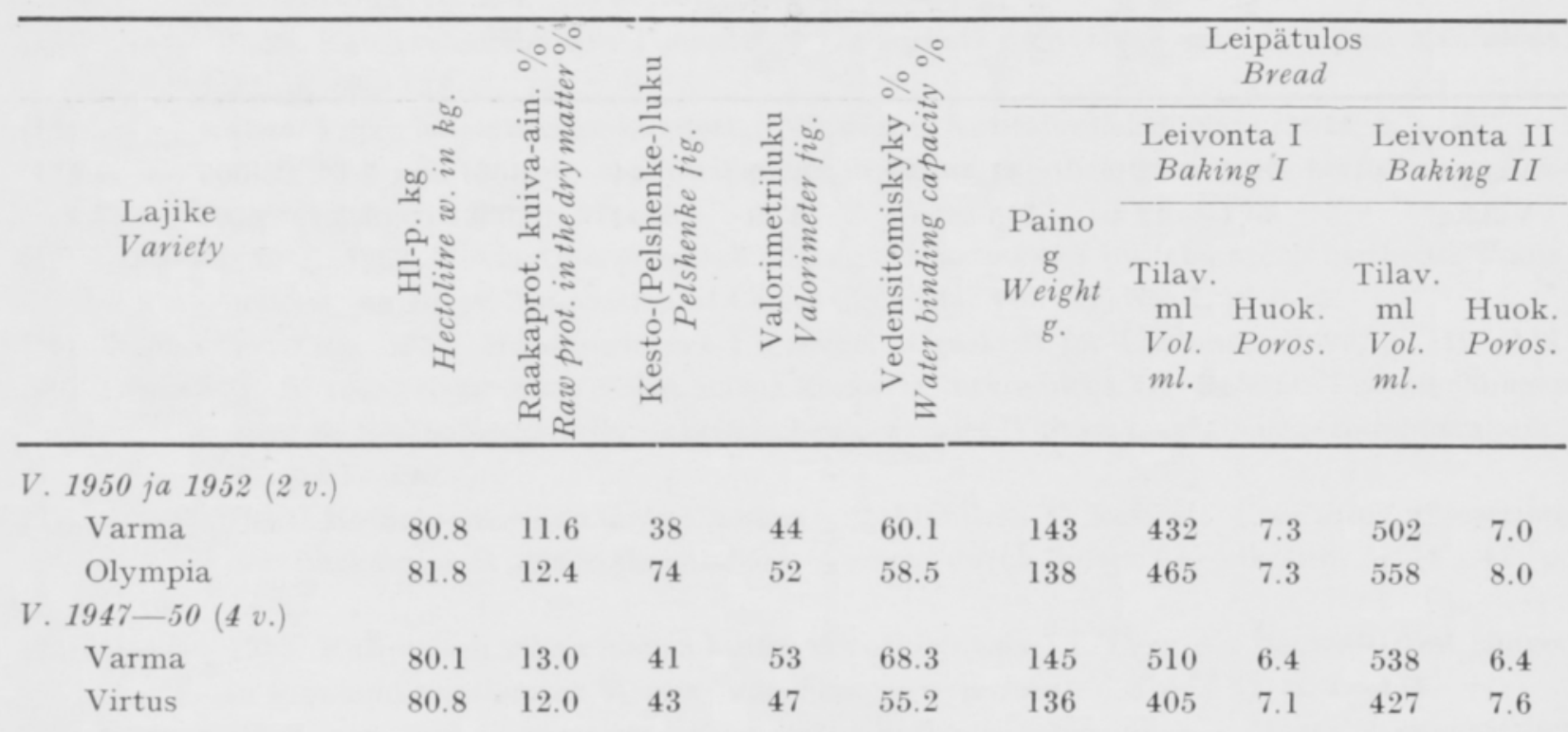


Taulukko 9. Varma- ja Olympia- $(1936-40,1945-47,1949-50)$ (11 v.) sekä Vakka- ja Virtus- (19471949 - 50) (3 v.) syysvehnäin valorimetriluvut sekä vedensitomiskyky Maatalouskoelaitoksen kasvin, jalostusosastolla suoritettujen määritysten mukaan.

Table 9. Valorimeter figures and waterbinding capacity of the winter wheat varieties Varma and Olympia $(1936-40,1945-47,1949-50,11$ years) and of Vakka and Virtus $(1947,1949-50,3$ years $)$ according to determinations carried out at the Agricultural Research Centre, Department of Plant Breeding.

\begin{tabular}{ccc}
\hline $\begin{array}{c}\text { Lajike } \\
\text { Variety }\end{array}$ & $\begin{array}{c}\text { Valorimetriluku } \\
\text { Valorimeter fig. }\end{array}$ & $\begin{array}{c}\text { Vedensitomis- } \\
\text { kyky \% } \\
\text { Water binding } \\
\text { capacity \% }\end{array}$ \\
\hline Varma & 48 & 62.6 \\
Olympia & 62 & 56.7 \\
Vakka & 54 & 58.7 \\
Virtus & 46 & 52.0
\end{tabular}

Taulukko 10. Vakka-syysvehnän leivontakelpoisuus verrattuna Varma-vehnään vv. 1948 - 52 (5 v.) V.t.t.

Tab le 11. Baking quality of the winter wheat variety Vakka as compared to Varma in $1949-1952$ (5 years) T.R.I.

\begin{tabular}{|c|c|c|c|c|c|c|c|c|c|c|}
\hline \multirow{3}{*}{$\begin{array}{l}\text { Lajike } \\
\text { Variety }\end{array}$} & \multirow{3}{*}{ 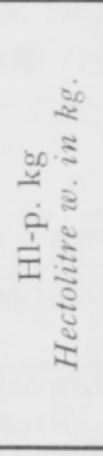 } & \multirow{3}{*}{ 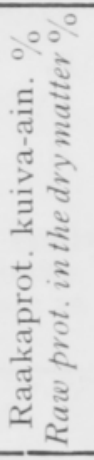 } & \multirow{3}{*}{ 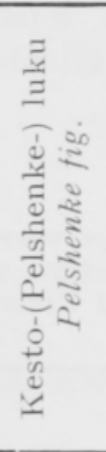 } & \multirow{3}{*}{ 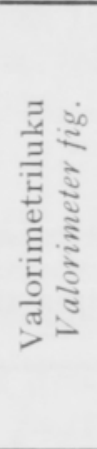 } & \multirow{3}{*}{ 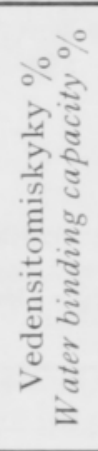 } & \multicolumn{5}{|c|}{$\begin{array}{c}\text { Leipätulos } \\
\text { Bread }\end{array}$} \\
\hline & & & & & & \multirow{2}{*}{$\begin{array}{c}\text { Paino } \\
\text { g } \\
\text { Weight } \\
\text { g. }\end{array}$} & \multicolumn{2}{|c|}{$\begin{array}{l}\text { Leivonta I } \\
\text { Baking I }\end{array}$} & \multicolumn{2}{|c|}{$\begin{array}{c}\text { Leivonta II } \\
\text { Baking II }\end{array}$} \\
\hline & & & & & & & $\begin{array}{c}\text { Tilav. } \\
\text { ml } \\
\text { Vol. } \\
\text { ml. }\end{array}$ & $\begin{array}{l}\text { Huok. } \\
\text { Poros. }\end{array}$ & $\begin{array}{c}\text { Tilav. } \\
\text { ml } \\
V o l . \\
m l .\end{array}$ & $\begin{array}{l}\text { Huok. } \\
\text { Poros. }\end{array}$ \\
\hline Varma & 79.2 & 13.0 & 41 & 53 & 67.9 & 144 & 466 & 7.1 & 505 & 6.8 \\
\hline Vakka & 80.4 & 12.4 & 115 & 61 & 63.9 & 141 & 500 & 7.5 & 561 & 7.9 \\
\hline
\end{tabular}




\section{KIRJALLISUUSLUETTELO}

(1) BeRG, S. O. 1946. Är vetemjölets örighetsgrad huvudsakligen en sortegenskap?. Agri Hortique Genetica, IV, p. 1-41.

(2) Fajersson, Fajer. 1953. Örigheten som växtodlingsproblem. Ibid. XI, p. 149-207.

(3) Kosmin, Natalie P. 1939. Das Problem der Backfähigkeit, p. 1-191.

(4) Miranda, H. De en Broekhuizen, 1953. Het probleem ven de bakkwaliteit van inlandse tarwe. Summary: The problem of baking quality in home grown wheat. Stichting voor coördinatie van cultuuren onderzoek van broodgraan, N:o 6, p. 1-19.

(5) Nuorteva, Pekra. 1953. Die Bedeutung mechanischer Schädigung des Weizenkorns durch Wanzen für das Korn und für die Backfähigkeit des Mehles. Suomen Hyönteistieteellinen Aikakauskirja - Annales Entomologici Fennici, 19, N:o 1, p. 29-33.

(6) Pelshenke, P. 1932. Beiträge zur Qualitätszüchtung des Weizens. Zeitschrift für Züchtung, Reihe A Pflanzenzüchtung, 18, Hefte 1, p. 1-18.

(7) $\longrightarrow$ 1938. About the world's wheat varieties. Institute of Baking at the Experimental Station for Grain Products, p. $1-8$.

(8) Pesola, Vilho A. 1937. Jokioisten kevätvehnäjalosteet. Valtion maatalouskoet. tiedonant. 129, p. $1-20$.

(9) —— 1938. Vehnä ja vehnäleipä muissa maissa ja Suomessa. Referat: Weizen und Weizenbrot innerhalb und ausserhalb Finnlands. Maataloustiet. aikakausk., 10, p. 165-187.

(10) —- 1953. Länsi-Saksan, Sveitsin ja Italian kasvinjalostuslaitoksiin tutustumassa. Maatalous, 46 , p. $279-282$.

(11) —- 1954. Syysvehnä leipäviljantuotantomme varmistajana. Summary: Winter wheat as a security factor in the production of bread corn in Finland. Maatalous ja Koetoiminta, 8, p. $107-123$.

(12) Pesola, Vilho A. och Otterström, Bengt. 1935. Bidrag till kännedom om vetets bakningsförmåga i Finland. Beretning fra N.J.F:s Kongres i Köbenhavn, Juli 1935, Sektion III, N:o 4, p. $1-14$.

(13) Pulkki, L. H. 1937. Eräiden Suomessa viljeltyjen vehnälaatujen myllytysarvosta. Maatalous, 30 , p. $6-11$.

(14) — - 1938. Particle size in relation to flour characteristics and starch cells of wheat. Cereal Chemistry, Vol. XV, N:o 6, November, p. 749-765.

(15) —- 1939. Kevätvehnälaatujen Timantti ja Timantti II myllytysarvojen vertailua. Maatalous, 32 , p. $68-72$.

(16) —- 1944. Viljan leivontakelpoisuudesta. Ylipainos, Kotitalouslehti, N:o 1, 1944, p. 1—8.

(17) —- 1950. Notes on the role of electrification in sifting. Nordisk Cerealkjemikerforenings kongress i Bergen 1950, p. $27-35$.

(18) Seeborg, E. F. 1953. Evaluation of wheat milling characteristics by laboratory methods. Transactions, American Association of Cereal Chemists, Vol. XI, N:o 1, p. 1-5.

(19) Thøgersen, Ole. 1954. Hvedesorternes bageevne. Ugeskrift for Landmaend, 99, p. 110-111.

(20) Tomula, E. S. 1928. Kotimaisen viljan laatua koskevia tutkimuksia II. Referat: Untersuchungen über die Beschaffenheit des einheimischen Getreides. Valtion maatalouskoetoiminnan julk., 20 , p. $1-105$.

(21) —- 1932. Kotimaisen viljan laatua koskevia tutkimuksia V. Referat: Über die Verbesserung der Backfähigkeit des einheimischen Weizens durch einige Chemikalien. Ibid., 47, p. $1-44$.

$(22) \longrightarrow$ 1933. Kotimaisen viljan laatua koskevia tutkimuksia VI. Über die Backfähigkeit einiger in Finnland angebauten Winter- und Sommerweizensorten. Ibid., 52, p. 1-145.

(23) Tomula, E. S. ym. 1927. Kotimaisen viljan laatua koskevia tutkimuksia I. Maatalousministeriön tiedonant., 8 , p. $1-95$.

(24) Veijola, Teemu. 1938 a. Eräiden uusien vehnäjalosteiden tutkimustuloksia. Maatalous, 31, p. $303-306$. 
(25) Veijola, Teemu. 1938 b. Selostus vuoden 1936 vehnäsatoa koskevista tutkimuksista. Referat: Bericht über die Untersuchungen bezüglich der Weizenernte 1936. Viljantutkimuslait. julk., 1, p. 1-129.

(26) —— 1941 a. Kotimaisen vehnän leivontakelpoisuudesta. Viljantutkimuslaitoksen suorittamien tutkimusten tuloksia. Viljantutkimuslait. Tiedonant., 5; ylipainos Maa-lehti, n:o 1-2 1941, p. $1-7$.

(27) — — 1941 b. Selostus vuoden 1939 vehnäsatoa koskevista tutkimuksista. Referat: Bericht über die Untersuchungen bezüglich der Weizenernte 1939. Viljantutkimuslait. julk. ,4, p. 1-70.

(28) — - 1948. Vehnän valkuaispitoisuudesta ja siihen vaikuttavista tekijöistä. Valtion teknillinen tutkimuslaitos, tiedoitus 63 , p. $1-18$.

(29) —- 1950. Eräistä uusista vehnäjalosteista ja niiden leivontakelpoisuudesta. Ibid., tiedoitus 86 , p. $1-18$.

(30) - - 1954 a. Kauppaviljan laatututkimuksia suoritettu 10 vuotta. Maatalous, 47, p. 97-100.

(31) —— 1954 b. Eräistä leivontatulokseen vaikuttavista tekijöistä. Leipuri, N:o 5 1954, p. 112 - 114.

(32) Åkerman, Å. 1935. Kvalitetsfrågan vid förädlingen av våra stråsädesslag. Beretning om Nordisk Jordbruksforskeres kongres i Köbenhavn 1935. Nordisk Jordbrugsforskning, Hefte, $4-7$, p. $554-571$.

(33) —— 1936. Die Verbesserung der Backfähigkeit des schwedischen Weizens durch Züchtung. Der Züchter, Heft 7-8, p. $174-179$.

(34) —— 1951. Vete. Allmän översikt. Svensk växtförädling, del I, p. 85-138.

(35) Åkerman, Å., Lindberg, J. E. och Augustin, S. 1953. Undersökningar av kvaliteten hos 1952 års brödsädesskörd. Sveriges Utsädesförenings tidskrift. Häfte 5 1953, p. 475-510.

SUMMARY:

ON BREEDING FOR QUALITY OF WHEAT IN FINLAND

Vilho A. Pesola and Teemu Veijola

Agricultural Research Centre, Department of Plant Breeding, Jokioinen and the State Institute of Technical Research, Helsinki, respectively.

W in ter wheat. As a result of Finnısh plant breeding work we have produced varieties which, with regard to their baking qualities (Olympia, Vakka) and milling qualities (Varma, Vakka) reach a fairly high or very high standard. The early ripening of winter wheat is likely to ensure good quality of the yield, whilst lodging and high rainfall in late summer may endanger it. Varma and Olympia have 'certain agrobiological weaknesses which limit their cultivation; Vakka promises well. In future breeding work, more attention should be paid to the milling qualities of the wheat.

$\mathrm{S}$ p ring w h e t. The available varieties ensure a satisfactory standard of the quality of spring wheat. Plant breeding work in Finland has succeeded in combining suitable early ripening and good baking qualities (class B or nearly A). In addition to their many favourable growing properties the Swedish varieties have the disadvantage of relatively late ripening, especially with regard to the production of quality wheat. With spring wheat special attention must be paid to early ripening of the varjeties, and suitable varieties must be found for each growing region.

At present the situation is such that in summers with normal or favourable weather conditions Finland is able to produce wheat of satisfactory quality. Summers with unfavourable weather conditions (chill, high rainfall, frost, etc.) especially affect the quality of spring wheat. For this reason, and also because of the relatively high yielding capacity of winter wheat, its cultivation should be extended.

The relatively high standard of quality of Finnish wheat varieties should be born in mind when we aim at self-sufficiency in wheat production and plan the importation of wheat from abroad. 